\title{
Evaluasi Kesesuaian Lahan Tanaman Jagung dan Kelapa Pada Lahan Praktek Sekolah Pertanian Pembangunan Kota Ambon, Provinsi Maluku
}

\section{Land Suitability Evaluation for Corn and Coconut in the Prantice Land of The Agricultural Development School of Ambon City, Maluku Province}

\section{Hendrico F. Hehakaya ${ }^{1}$, Willem A. Siahaya², Rafael M. Osok ${ }^{2 * *}$}

\author{
${ }^{1}$ Program Studi Pengelolaan Lahan, Program Pascasarjana Universitas Pattimura, Jln. Dr. Tamaela, Ambon 97112, \\ Indonesia \\ ${ }^{2}$ Jurusan Budidaya Pertanian, Fakultas Pertanian, Universitas Pattimura, Jl. Ir. M. Putuhena, Kampus Poka, Ambon \\ 97233, Indonesia \\ *E-mail Penulis Korespondensi: rafmosok2016@gmail.com
}

\begin{abstract}
The basic role of land evaluation is to assess the suitability of a land for a particular use. The student practical land of Ambon Agricultural Development School have been utilized without land an evaluation study. This research aimed to determine land suitability for of corn (Zea mays L.) and coconut (Cocos nucifera L.) and to propose the land improvement practices for the student practical land. The method used was a survey with a synthetic approach. The obervation type was Rigrid Grid with $20 \mathrm{~m}$ distance between lines and points observation. The results showed three land suitability classes for corn and coconut cultivation, namely S3 (marginally suitable), N1 (currently not suitable) and N2 (permanently not suitable). The limiting factors for land use were root media, nutrient retention, nutrient availability and slope. Improvement efforts to overcome the limiting factors of BS (base saturation) for the cultivation of corn and coconut could be done by liming or adding organic matter, with moderate management. The limiting factors of $\mathrm{N}$-total, and $\mathrm{P}_{2} \mathrm{O}_{5}$ could be improved by fertilization, with a low to moderate level of management, while the slope limiting factor could not be improved due to very high costs. Based on the soil fertility criteria, the soil fertility status of the study area is low and very low.
\end{abstract}

Keywords: Ambon City, coconut, corn, land suitabilit, school practical land

\section{ABSTRAK}

Peran dasar evaluasi lahan adalah menilai kesesuaian lahan untuk penggunaan tertentu. Lahan praktek siswa Sekolah Pengembangan Pertanian Ambon telah dimanfaatkan tanpa melalui studi evaluasi lahan yang memadai sehingga hasil yang diperoleh belum optimal. Untuk itu perlu dilakukan evaluasi kesesuaian lahan dalam bentuk penelitian. Penelitian ini bertujuan untuk menetapkan kelas dan sub kelas kesesuaian lahan dan faktor pembatas untuk budidaya tanaman jagung (Zea mays L.) dan kelapa (Cocos nucifera L.) serta merekomendasikan tindakan perbaikan lahan. Metode yang digunakan adalah metode survei dengan pendekatan sintetik dan tipe observasi Rigrid Grid. Jarak jalur observasi dan jarak titik pengamatan dalam jalur 20 meter. Hasil penilaian menunjukkan tiga kelas kesesuaian lahan untuk tanaman jagung dan kelapa, yaitu S3 (sesuai marginal), N1 (tidak sesuai saat ini) dan N2 (tidak sesuai selamanya). Faktor pembatas untuk pemanfaatan lahan adalah media perakaran, retensi hara, ketersediaan hara dan kelerengan. Upaya perbaikan untuk mengatasi faktor pembatas KB (kejenuhan basa) untuk budidaya tanaman jagung dan kelapa dapat dilakukan dengan cara pengapuran atau penambahan bahan organik, dengan tingkat pengelolaan sedang. Sedangkan perbaikan terhadap faktor pembatas $\mathrm{N}$-total, dan $\mathrm{P}_{2} \mathrm{O}_{5}$ dapat dilakukan dengan cara pemupukan, dengan tingkat pengelolaan rendah sampai sedang. Untuk faktor pembatas kelerengan tidak dapat dilakukan perbaikan karena sulit diatasi dan memerlukan biaya yang sangat tinggi. Berdasarkan kriteria kesuburan tanah, status kesuburan tanah lokasi penelitian berkisar dari sangat rendah sampai rendah.

Kata kunci: jagung, lahan praktek sekolah, kelapa, kesesuaian lahan, kota Ambon

\section{PENDAHULUAN}

Pemanfaatan sumberdaya lahan secara optimal sesuai dengan peruntukannya akan berdampak pada kelestarian usaha dan sebaliknya apabila pemanfaatannya tidak sesuai dengan peruntukannya maka lahan akan mengalami kerusakan. Hal ini dapat dilakukan apabila data dan informasi tentang potensi sumberdaya lahan tersebut telah diketahui. Untuk mengetahui potensi sumberdaya lahan dimaksud dapat 
dilakukan dengan cara evaluasi lahan. Evaluasi lahan memberikan pengertian tentang hubungan-hubungan antara kondisi lahan dan menilai kesesuaian lahan bagi pemanfaatannya. Peranan dasar dari evaluasi lahan adalah untuk menilai kesesuaian lahan bagi suatu penggunaan tertentu serta memprediksi konsekuensikonsekuensi yang akan muncul dari penggunaan lahan tersebut (Louhenapessy, 2004).

Sebagai sumber daya alam yang terdiri dari tanah dan kondisi lingkungan, lahan sering memiliki kendala dalam pemanfaatannya. Oleh sebab itu, diperlukan perencanaan yang tepat agar dapat digunakan secara efektif dan berkelanjutan. Salah satu cara yang harus dilakukan untuk menjaga tanah dari kerusakan adalah dengan menggunakan tanah sesuai dengan kemampuan dan kelayakannya (Lehmann dan Stahr, 2010; Hafif, Barus and Misganti, 2013). Dengan demikian, evaluasi kesesuaian suatu lahan serta perencanaan pemanfaatannya untuk tanaman tertanian punya peran penting agar nantinya lahan bermanfaat secara optimal dan berkelanjutan

Kelas kesesuaian lahan pada dasarnya ditentukan oleh kecocokan antara lingkungan fisik dan persyaratan penggunaan lahan atau persyaratan tumbuh tanaman. Kecocokan antara sifat fisik lingkungan dengan persyaratan penggunaan lahan atau persyaratan tumbuh tanaman memberikan gambaran bahwa lahan tersebut potensial untuk dikembangkan. Hal ini mempunyai pengertian bahwa jika lahan tersebut digunakan untuk penggunaan tertentu dengan mempertimbangkan berbagai asumsi mencakup masukan yang diperlukan akan mampu memberikan hasil (keluaran) sesuai dengan yang diharapkan (Djaenudin et al., 2000).

Pemanfaatan lahan praktek siswa pada Lahan Praktek Unit Pelaksana Teknis Daerah (UPTD) Sekolah Pengembangan Pertanian (SPP) Ambon selama ini dilakukan secara alami tanpa melalui satu kajian evaluasi lahan yang memadai sehingga hasil yang didapat masih belum optimal. Untuk mendapatkan hasil yang optimal maka perlu dilakukan kajian evaluasi lahan yang mendalam untuk berbagai bentuk penggunaan, baik untuk budidaya tanaman pangan, tanaman hortikultura maupun tanaman perkebunan. Hasil kajian evaluasi lahan diharapkan dapat memberikan rekomendasi yang tepat terhadap pemanfaatan lahan praktek dalam bentuk kelas-kelas kesesuaian lahan.

Berdasarkan pada latar belakang tersebut di atas maka kajian evaluasi kesesuaian lahan tanaman jagung dan kelapa pada Sekolah Pertanian Pembangunan Provinsi Maluku di Desa Passo, Ambon, perlu dilakukan dalam bentuk penelitian. Penelitian ini bertujuan untuk: 1) Menetapkan kelas dan sub kelas kesesuaian lahan dan faktor pembatas untuk tanaman jagung (Zea mays L.) dan kelapa (Cocos nucifera L.) dan 2) merekomendasikan tindakan perbaikan lahan.

\section{BAHAN DAN METODE}

\section{Tempat dan Waktu}

Penelitian ini dilaksanakan pada UPTD SPP Provinsi Maluku di Desa Passo Kecamatan Baguala Kota Ambon, Provinsi Maluku. Kegiatan penelitian berlangsung selama bulan September 2018.

\section{Metode Penelitian}

Metode penelitian adalah survei dengan pendekatan sintetik melalui observasi rigrid grid, dengan jarak antar jalur dan titik observasi adalah 20 meter. Pengamatan tanah dilakukan dengan pengamatan identifikasi (boring). Tanah-tanah yang diidentifikasi di lapangan kemudian ditentukan jenis/macam tanah berdasarkan Sistem Klasifikasi Tanah Nasional (PPT, 2014) dan padanannya dengan Sistem Klasifikasi Taksonomi Tanah USDA (Soil Survey Staff, 2014).

Berdasarkan data boring ditetapkan lokasi pengamatan profil dan pengambilan sample tanah. Pengambilan contoh tanah kesuburan secara komposit. Contoh tanah dianalisis pada Laboratorium Pusat Penelitian Tanah Maros, Makassar, meliputi distribusi partikel, kandungan karbon, N, P, K, pH dan basa-basa meliputi $\mathrm{Ca}, \mathrm{Mg}$, Na, K serta KTK.

Pengolahan dan analisis data meliputi tabulasi data karakteristik dan kualitas lahan, kemudian ditetapkan kelas kesesuaian lahan menggunakan metode perbandingan antara kualitas lahan dengan syarat tumbuh tanaman (Hardjowigeno dan Widiatmaka, 2007).

\section{Letak dan Luas Wilayah}

Secara administrasi pemerintahan, lokasi penelitian masuk dalam wilayah Kecamatan Baguala Kota Ambon seluas 5,7 ha. Secara geografis lokasi penelitian sebelah Utara berbatasan dengan laut, sebelah Selatan dengan petuanan Negeri Passo, sebelah Timur dengan petuanan Negeri Passo dan sebelah Barat berbatasan dengan petuanan Desa Lateri. Secara astronomi lokasi penelitian berada pada koordinat 416100-416750 M Utara dan 9597650-959750 M Timur. Lokasi penelitian berada pada topografi datar sampai berbukit dengan ketinggian 0-100 $\mathrm{m}$ di atas permukaan laut (dpl).

\section{HASIL DAN PEMBAHASAN}

\section{Geologi}

Berdasarkan peta geologi Pulau Ambon skala 1:400.000 (Lembaga Penelitian Universitas Pattimura), geologi lokasi penelitian terdiri dari batuan vulkanik Ambon dan konglomerat. Dalam penelitian lapangan, bahan induk yang ditemukan adalah bahan lepas (loss material) 


\section{Topografi}

Lokasi penelitian berada pada topografi datar sampai berbukit dengan tingkat lereng 0- -3\% (datar), 38\% (landai/berombak), 8-15\% (bergelombang), 15-30\% (agak curam); 30-45\% (sangat curam) dan > 45\% (ekstrim curam).

Tabel 1. Karakteristik topografi Kebun Praktek UPTD SPP Provinsi Maluku di Desa Passo

\begin{tabular}{ccccc}
\hline No & Kemiringan & Kelas Lereng & \multicolumn{2}{c}{ Luas } \\
\cline { 3 - 5 } & lereng & & Ha & $\%$ \\
\hline 1 & $0-3 \%$ & Datar & 2,93 & 51,16 \\
2 & $3-8 \%$ & Landai & 0,28 & 4,86 \\
3 & $8-15 \%$ & Agak miring & 0,13 & 2,24 \\
4 & $15-30 \%$ & Miring & 1,02 & 17,88 \\
5 & $>45 \%$ & Curam & 1,36 & 23,86 \\
\hline & Total & & 5,72 & 100,00 \\
\hline
\end{tabular}

Sumber: Penelitian lapangan, 2018

\section{Iklim}

Informasi keadaan iklim di lokasi penelitian diperoleh dari Stasiun BMKG Lanud Pattimura, Ambon, selama 10 tahun periode pengamatan (20082018), sebagaimana disajikan pada Tabel 2.

Lokasi penelitian termasuk iklim $\mathrm{C} 1$ menurut Oldeman (1975), karena memiliki 5 bulan basah, yaitu bulan dengan curah hujan $>200 \mathrm{~mm}$ terjadi pada bulan Mei-September, dan 1 bulan kering, yaitu bulan dengan curah hujan $<100 \mathrm{~mm}$ terjadi pada bulan November. Data menunjukan bahwa jumlah curah hujan tahunan adalah $3733,9 \mathrm{~mm}$ dengan rata-rata bulanan $372,4 \mathrm{~mm}$, dengan curah hujan bulanan tertinggi $769,9 \mathrm{~mm}$ pada bulan Juli dan curah hujan bulanan terendah 68,5 mm pada bulan November. Rata-rata hari hujan adalah 19,8 hari, dengan hari hujan tertinggi 26,9 hari pada bulan Juli dan terendah 11,5 hari pada bulan November. Kriteria klasifikasi iklim menurut Oldeman (1975) disajikan pada Tabel 3.

Berdasarkan hasil perhitungan nilai Q menurut Schmidt dan Ferguson (1951) dalam Talakua (2016), lokasi penelitian memiliki nilai Q sebesar 0,103, termasuk dalam klasifikasi iklim A, yaitu sangat basah. Nilai Q sebesar 0,103 didapat dari hasil bagi rata-rata bulan kering $(\mathrm{BK}=1$ bulan) dengan rata-rata bulan basah $(\mathrm{BB}=9,7$ bulan) dikalikan dengan 100 persen. Kriteria perhitungan nilai Q disajikan pada Tabel 4.

\section{Suhu Udara dan Kelembaban}

Suhu rata-rata $26,8^{\circ} \mathrm{C}$ dan kelembaban rata-rata $84,7 \%$. Rata-rata suhu tertinggi terjadi pada bulan Januari $28^{\circ} \mathrm{C}$ dan rata-rata suhu terendah pada bulan Agustus $25,3^{\circ} \mathrm{C}$. Suhu maximum $31,9^{\circ} \mathrm{C}$ terjadi pada bulan Februari dan suhu udara minimum $23,1^{\circ} \mathrm{C}$ pada bulan Agustus. Kelembaban tertinggi pada bulan Juli $88,8 \%$ dan terendah pada bulan Desember $81,2 \%$.

\section{Tanah}

Tanah di lokasi penelitian adalah Kambisol, yang terbentuk dari formasi batuan gunung api Ambon. Tanah di lokasi penelitian mempunyai solum dalam (100-120 cm), tekstur lempung pada lapisan atas, dan lempung liat hingga lempung liat berpasir pada lapisan bawa. Kemasaman tanah ( $\mathrm{pH}$ lapangan) berkisar 6.0. sifat kimia tanah adalah sebagai berikut.

Tabel 2. Data suhu udara, curah hujan, hari hujan dan kelembaban nisbi udara di lokasi penelitian periode 10 tahun pengamatan (2008 - 2018)

\begin{tabular}{|c|c|c|c|c|c|c|}
\hline \multirow[b]{2}{*}{ Bulan } & \multicolumn{3}{|c|}{ Temperatur $\left({ }^{\circ} \mathrm{C}\right)$} & \multirow{2}{*}{$\begin{array}{c}\text { Curah Hujan } \\
(\mathrm{mm})\end{array}$} & \multirow{2}{*}{$\begin{array}{l}\text { Hari Hujan } \\
\quad \text { (hari) }\end{array}$} & \multirow{2}{*}{$\begin{array}{c}\text { Kelembaban Nisbi } \\
(\%)\end{array}$} \\
\hline & Rata-Rata & Max. & Min. & & & \\
\hline Januari & 27,3 & 31,7 & 24,1 & 199,5 & 19,7 & 82,0 \\
\hline Pebruari & 27,2 & 31,9 & 23,9 & 131,6 & 18,2 & 81,7 \\
\hline Maret & 27,3 & 31,8 & 24,1 & 139,1 & 17,2 & 82,1 \\
\hline April & 27,0 & 31,2 & 24,1 & 194,1 & 20,8 & 85,0 \\
\hline Mei & 26,6 & 30,2 & 24,2 & 577,0 & 25,0 & 87,9 \\
\hline Juni & 25,7 & 28,9 & 23,7 & 694,7 & 25,4 & 88,3 \\
\hline Juli & 25,4 & 28,2 & 23,5 & 769,7 & 26,9 & 88,8 \\
\hline Agustus & 25,3 & 28,3 & 23,1 & 413,5 & 24,6 & 87,1 \\
\hline September & 25,9 & 29,3 & 23,2 & 264,0 & 16,5 & 86,1 \\
\hline Oktober & 26,8 & 30,6 & 23,7 & 129,5 & 13,0 & 83,9 \\
\hline November & 28,0 & 31,0 & 24,1 & 68,5 & 11,5 & 81,7 \\
\hline Desember & 27,6 & 31,7 & 25,1 & 152,4 & 19,1 & 81,2 \\
\hline Jumlah & - & - & - & 3733,9 & 237,9 & - \\
\hline Rata-Rata & & & & & & \\
\hline Bulanan & 26,7 & 30,4 & 30,4 & 373,4 & 19,8 & 84,7 \\
\hline
\end{tabular}

Sumber : Stasiun BMKG Lanud Pattimura Laha, Ambon 2018 
Tabel 3. Klasifikasi iklim menurut Oldeman (1975)

\begin{tabular}{ccc}
\hline Tipe Iklim & Bulan Basah & Bulan Kering \\
\hline A1 & $>9$ & $<2$ \\
A2 & $>9$ & $2-4$ \\
B1 & $7-9$ & $<2$ \\
B2 & $7-9$ & $2-4$ \\
B3 & $7-9$ & $5-6$ \\
C1 & $5-6$ & $<2$ \\
C2 & $5-6$ & $2-4$ \\
C3 & $5-6$ & $5-6$ \\
C4 & $5-6$ & $>6$ \\
D1 & $3-4$ & $<2$ \\
D2 & $3-4$ & $2-4$ \\
D3 & $3-4$ & $5-6$ \\
D4 & $3-4$ & $>6$ \\
E1 & $<3$ & $<2$ \\
E2 & $<3$ & $2-4$ \\
E3 & $<3$ & $5-6$ \\
E4 & $<3$ & 6 \\
\hline
\end{tabular}

Tabel 4. Kriteria klasifikasi iklim menurut Schmidt Fergusson (1951)

\begin{tabular}{ccc}
\hline Iklim & Nilai Q & Sifat \\
\hline A & $0-0,143$ & Sangat basah \\
B & $0,143-0,333$ & Basah \\
C & $0,333-0,600$ & Agak basah \\
D & $0,600-1,000$ & Sedang \\
E & $1,000-1,670$ & Agak kering \\
F & $1,670-3,000$ & Kering \\
G & $3,000-7,000$ & Sangat kering \\
H & $>7,000$ & Ekstrim \\
\hline
\end{tabular}

Kejenuhan basa (\%)

Kejenuhan basa adalah perbedaan antara jumlah kation basa dengan semua jumlah kation ( kation asam dan basa ) dalam jerapan koloid.

Hasil analisis di lokasi penelitian menunjukkan bahwa nilai $\mathrm{KB} 38 \%$ (sedang) dengan luas 1,45 ha $(23,52 \%)$, KB $7 \%$ (sangat rendah) dengan luas 1,34 ha $(23,52 \%)$, KB $18 \%$ (rendah) dengan luas 2,93 ha $(51,16 \%)$.

Tabel 5. Kejenuhan basa tanah di Kebun Praktek UPTD SPP Provinsi Maluku di Desa Passo

\begin{tabular}{ccccc}
\hline No. & $\begin{array}{c}\text { Kejenuhan } \\
\text { Basa }\end{array}$ & $\begin{array}{c}\text { Tanah } \\
\text { Nasional }\end{array}$ & $\begin{array}{c}\text { Luas } \\
(\text { ha })\end{array}$ & $\begin{array}{c}\text { Luas } \\
(\%)\end{array}$ \\
\hline & KB sangat & Kambisol & & \\
1 & rendah & & 1,34 & 23,52 \\
2 & KB rendah & Kambisol & 2,93 & 51,16 \\
3 & KB sedang & Kambisol & 1,45 & 25,32 \\
\hline & Total & Kambisol & 5,72 & 100,00 \\
\hline
\end{tabular}

Sumber : Hasil Penelitian, 2018

\section{KTK Tanah (cmol) dan pH $\mathrm{H}_{2} \mathrm{O}$}

Kapasitas Tukar Kation (KTK) tanah adalah kemampuan suatu tanah untuk mempertukarkan ion di dalam tanah (Hanafiah, 2008). Hasil penilaian KTK tanah pada lokasi penelitian umumnya rendah berkisar dari 7,00 mg/100g-15,96 mg/100g.nilai KTK yang baik untuk pertumbuhan dan produksi tanaman kelapa adalah tinggi (>25mg/100g) (Tabel 9). Hasil analisis tanah di lokasi penelitian menunjukkan bahwa $\mathrm{pH}$ tanah semua sampel adalah rendah atau bersifat masam.

Reaksi tanah menunjukkan sifat kemasaman alkanitas tanah yang dinyatakan dengan nilai $\mathrm{pH}$. Nilai $\mathrm{pH}$ berkisar dari 0-14 dengan $\mathrm{pH} 7$ adalah netral, sedangkan $\mathrm{pH}<7$ adalah masam dan $\mathrm{pH}>7$ disebut basa atau alkalis. Pentingnya $\mathrm{pH}$ tanah untuk menentukan mudah tidaknya unsur-unsur hara diserap oleh tanaman. Pada umumnya unsur hara mudah diserap oleh akar tanaman pada $\mathrm{pH}$ tanah sekitar netral. Selain itu $\mathrm{pH}$ tanah juga dapat mempengaruhi perkembangan mikro organisme.

\section{C-organik}

Berdasarkan hasil analisis C-organik di lokasi penelitian menunjukkan bahwa kandungan bahan organik yang terdapat di dalam tanah berkisar dari rendah sampai tinggi, kandungan bahan organik pada setiap tanah mempunyai kandungan organik yang berbeda.

\section{Penggunaan Lahan dan Vegetasi}

Berdasarkan hasil pengamatan lapangan, bentuk penggunaan lahan yang ditemukan adalah perkebunan dan pangan hortikultura dengan sistem polikultur. Tanaman kelapa (Cocos nucifera) sebagai tanaman utama dan tanaman kakao (Theobroma cacao) dan karet (Hevea brasiliensis), sedangkan untuk tanaman pangan ditanami jagung (Zea mays). Vegetasi penutup lahan yang ditemukan adalah alang-alang (Imperata cylindrica), sungga-sungga (Eupatrium odoratum), rumput-rumputan (Catex sp), dan paku-pakuan (Selanginella $\mathrm{sp}$ ).

Tabel 6 menunjukkan tipe penggunaan lahan di kebun praktek UPTD SPP Provinsi Maluku, tipe penggunaan lahan terbesar adalah hutan sekunder adalah 2,972 ha atau $51,985 \%$. Selanjutnya diikuti oleh tipe penggunaan lahan 0,638 ha atau $11,162 \%$ sebagai perumahan dan tipe penggunaan lahan terkecil adalah green house 0,001 ha atau $0,021 \%$ dan gudang penampung hasil panen 0,001 ha atau $0,023 \%$.

\section{Kesesuaian Lahan Tanaman Jagung dan Kelapa}

Kesesuaian lahan yang dihasilkan berdasarkan data yang diperoleh belum mempertimbangkan asumsi atau usaha perbaikan dan tingkat pengolahan yang dilakukan untuk mengatasi faktor-faktor pembatas yang ada pada setiap unit lahan. Kesesuaian lahan untuk kedua tanaman ini diperoleh dari pengelolaan data dilapangan dan hasil analisis laboratorium. 
Tabel 6. Tipe penggunaan lahan di Kebun Praktek UPTD SPP Provinsi Maluku di Desa Passo

\begin{tabular}{|c|c|c|c|c|}
\hline \multirow{2}{*}{ No. } & \multirow{2}{*}{$\begin{array}{c}\text { Tipe Penggunaan } \\
\text { Lahan }\end{array}$} & \multirow{2}{*}{ KODE } & \multicolumn{2}{|c|}{ Luas } \\
\hline & & & ha & $\%$ \\
\hline 1 & Tanaman pisang & $\mathrm{E}$ & 0,165 & 2,890 \\
\hline 2 & $\begin{array}{l}\text { Tan hortikultura } \\
\text { buahan } \\
\text { Rumah sawung }\end{array}$ & $\mathrm{C}$ & 0,158 & 2,769 \\
\hline 3 & belajar & $\mathrm{L}$ & 0,008 & 0,134 \\
\hline 4 & Rumah penduduk & A & 0,638 & 11,162 \\
\hline 5 & $\begin{array}{l}\text { Rumah pegawai } \\
\text { Pohon bercampur }\end{array}$ & $\mathrm{L}$ & 0,056 & 0,980 \\
\hline 6 & semak & I & 0,175 & 3,064 \\
\hline 7 & $\begin{array}{l}\text { Pohon bamboo } \\
\text { Lahan latihan }\end{array}$ & $\mathrm{J}$ & 0,037 & 0,645 \\
\hline 8 & $\begin{array}{l}\text { tractor } \\
\text { Kebun tanaman }\end{array}$ & $\mathrm{L}$ & 0,169 & 2,964 \\
\hline 9 & tahunan & $\mathrm{D}$ & 0,179 & 3,136 \\
\hline 10 & Kebun kelapa & G & 0,130 & 2,268 \\
\hline 11 & Kebun karet & $\mathrm{H}$ & 0,190 & 3,319 \\
\hline 12 & $\begin{array}{l}\text { Kebun kakao } \\
\text { Kebun horti }\end{array}$ & $\mathrm{F}$ & 0,243 & 4,248 \\
\hline 13 & sayur & B & 0,586 & 10,250 \\
\hline 14 & $\begin{array}{l}\text { Hutan sekunder } \\
\text { Gudang } \\
\text { penampung hasil }\end{array}$ & $\mathrm{K}$ & 2,972 & 51,985 \\
\hline 15 & panen & $\mathrm{L}$ & 0,001 & 0,023 \\
\hline 16 & Gudang pacul & $\mathrm{L}$ & 0,006 & 0,108 \\
\hline 17 & $\begin{array}{l}\text { Green house } \\
\text { Bak penampung }\end{array}$ & $\mathrm{L}$ & 0,001 & 0,021 \\
\hline 18 & air & $\mathrm{L}$ & 0,002 & 0,033 \\
\hline & Total & & 5,718 & 100,000 \\
\hline
\end{tabular}

Sumber : Penelitian Lapangan, 2018

\section{Kelas kesesuian lahan aktual untuk tanaman jagung}

Tabel 7 menunjukkan bahwa pada lokasi penelitian terdapat 3 kelas kesesusaian lahan aktual untuk tanaman jagung, dengan beberapa sub kelas yang memiliki faktor pembatas berbeda. Berikut ini merupakan penjelasan dari setiap kelas kesesuaian serta sub kelas kesesuaian lahan dengan faktor pembatasnya masing-masing.

Kelas Kesesuaian Lahan S3

Kelas kesesuaian lahan sesuai marjinal (S3) terdapat pada area seluas 3.0085 ha atau $52.37 \%$ dari total luas lokasi penelitian . Kelas ini terbagi dalam satu sub kelas kesesuaian lahan, yaitu sub kelas (S3 rc, nr, n). Sub kelas kesesuaian lahan S3 rc, nr, n memiliki luasan 3.0085 ha atau $52.37 \%$. Sub kelas ini memiliki faktor pembatas berupa media perakaran, retensi hara, dan ketersediaan hara. Sub kelas kesesuaian lahan ini tersebar dalam sembilan belas SPL, dengan SPL terbesar L02b2 (0.5625 ha atau 9.84\%) dan lauasan terkecil adalah L01d2 (0.0009 ha atau $0.02 \%)$.

Kelas Kesesuaian Lahan N1

Kelas kesesuaian untuk lahan tidak sesuai (N1) terdapat pada area seluas 1.3446 ha atau $23.52 \%$ dari total luas lokasi penelitian. Kelas ini terbagi dalam dua sub kelas kesesuaian lahan, yaitu sub kelas (N1 n,nr), (N1 n,nr,eh).

a. Sub kelas kesesuaian lahan N1 n, nr memiliki luasan 0.3225 ha atau $5.64 \%$. Sub kelas ini memiliki faktor pembatas berupa ketersediaan hara dan retensi hara. Sub kelas kesesuaian lahan ini terdapat pada dua SPL, yaitu L11k1, L21k1

b. Sub kelas kesesuaian lahan N1 n,nr,eh memiliki luasan 1.0221 ha atau $17.88 \%$. Sub kelas ini memiliki faktor pembatas berupa ketersediaan hara, retensi hara dan lereng. Sub kelas kesesuaian lahan ini tersebar dalam enam SPL, dengan SPL terbesar L31k1 (0.6534 ha atau $11.43 \%)$ dan lauasan terkecil adalah L3111 (0.0003 ha atau $0.01 \%$ ).

\section{Kelas Kesesuian lahan N2}

Kelas kesesuaian untuk lahan tidak sesuai (N2) terdapat pada area seluas 1.3645 ha atau $23.87 \%$ dari total luas lokasi penelitian. Kelas ini terbagi dalam satu sub kelas kesesuaian lahan, yaitu sub kelas (N2 eh).

Sub kelas kesesuaian lahan N1 eh memiliki luasan 1.3645 ha atau $23.87 \%$. Sub kelas ini memiliki faktor pembatas berupa lereng. Sub kelas kesesuaian lahan ini tersebar dalam tiga SPL, dengan SPL terbesar L51k3 (1.2393 ha atau 21.68\%) dan luasan terkecil adalah L51h3 ( 0.0122 ha atau $0.21 \%$ ).

\section{Kelas kesesuian lahan aktual untuk tanaman kelapa}

Dari Tabel 8 dapat dijelaskan bahwa pada lokasi penelitian terdapat 3 kelas kesesusaian lahan Aktual untuk tanaman kelapa dengan beberapa sub kelas yang memiliki faktor pembatas berbeda. Berikut ini merupakan penjelasan dari setiap kelas kesesuaian serta sub kelas kesesuaian lahan dengan faktor pembatasnya masing-masing.

\section{Kelas Kesesuaian Lahan S3}

Kelas kesesuaian lahan sesuai marjinal (S3) terdapat pada area seluas 3.0085 ha atau $52.37 \%$ dari total luas lokasi penelitian . Kelas ini terbagi dalam dua sub kelas kesesuaian lahan, yaitu sub kelas (S3 rc, nr, n) dan (S3 nr,n,eh)

a. Sub kelas kesesuaian lahan S3 nr, n memiliki luasan 2.9251 ha atau 50.91\%. Sub kelas ini memiliki faktor pembatas berupa retensi hara, dan ketersediaan hara. Sub kelas kesesuaian lahan ini tersebar dalam delapan belas SPL, dengan SPL terbesar L02b2 (0.5625 ha atau $9.84 \%)$ dan lauasan terkecil adalah L01d2 (0.0009 ha atau $0.02 \%$ ).

b. Sub kelas kesesuaian lahan S3 nr,n,eh memiliki luasan 0.0834 ha atau $1.46 \%$. Sub kelas ini memiliki faktor pembatas berupa retensi hara, ketersediaan hara dan lereng. Sub kelas kesesuaian lahan ini hanya terdapat pada satu SPL, yaitu L2lk3. 
Tabel 7. Kesesuian lahan aktual untuk tanaman jagung di Kebun Praktek UPTD SPP Provinsi Maluku

\begin{tabular}{|c|c|c|c|c|c|c|}
\hline \multirow[t]{2}{*}{ No. } & \multirow{2}{*}{$\begin{array}{l}\text { KKL } \\
\text { Aktual }\end{array}$} & \multirow{2}{*}{$\begin{array}{c}\text { Sub } \\
\text { Kelas }\end{array}$} & \multirow{2}{*}{$\begin{array}{l}\text { Faktor } \\
\text { Pembatas }\end{array}$} & \multirow[t]{2}{*}{ Satuan Penggunaan Lahan } & \multicolumn{2}{|c|}{ Luas } \\
\hline & & & & & $\mathrm{Ha}$ & $\%$ \\
\hline \multirow[t]{3}{*}{1} & S3 & S3 rc,nr,n & Media perakaran, & L01a2 L01b2 L01d2 L01f2 L01g2 L01h2 & 3.0085 & 52.37 \\
\hline & & & retensi hara & L01i2 L01k2 L0112 L02a2 L02b2 L02c2 & & \\
\hline & & & ketersediaan hara & $\begin{array}{l}\text { L02d2 L02e2 L02i2 L02j2 L02k2 L0212 } \\
\text { L21k3 }\end{array}$ & & \\
\hline \multirow[t]{2}{*}{2} & N1 & $\mathrm{N} 1 \mathrm{nr}, \mathrm{n}$ & $\begin{array}{l}\text { Retensi hara, } \\
\text { ketersediaan hara }\end{array}$ & L11k1 L21k1 & 0.3225 & 5.64 \\
\hline & & N1 nr,n,eh & $\begin{array}{l}\text { Retensi hara, } \\
\text { ketersediaan hara, } \\
\text { lereng }\end{array}$ & L31f1 L31g1 L31h1 L31i1 L31k1 L3111 & 1.0221 & 17.88 \\
\hline \multirow[t]{2}{*}{3} & N2 & $\mathrm{N} 2 \mathrm{eh}$ & Lereng & L51f3 L51h3 L51k3 & 1.364 & 23.87 \\
\hline & & & & Total & 5.7176 & 100.00 \\
\hline
\end{tabular}

Tabel 8. Kesesuian Lahan Aktual Untuk Tanaman Kelapa di kebun praktek UPTD SPP Provinsi Maluku

\begin{tabular}{|c|c|c|c|c|c|c|}
\hline \multirow[t]{2}{*}{ No. } & \multirow{2}{*}{$\begin{array}{l}\text { KKL } \\
\text { Aktual }\end{array}$} & \multirow{2}{*}{$\begin{array}{c}\text { Sub } \\
\text { Kelas }\end{array}$} & \multirow{2}{*}{$\begin{array}{l}\text { Faktor } \\
\text { Pembatas }\end{array}$} & \multirow[t]{2}{*}{ Satuan Penggunaan Lahan } & \multicolumn{2}{|c|}{ Luas } \\
\hline & & & & & $\mathrm{Ha}$ & $\%$ \\
\hline \multirow[t]{4}{*}{1} & S3 & S3 nr,n & Media & L01a2 L01b2 L01d2 L01f2 L01g2 L01h2 & & \\
\hline & & & perakaran, & L01i2 L01k2 L0112 L02a2 L02b2 L02c2 & 2.9251 & 50.91 \\
\hline & & & $\begin{array}{l}\text { retensihara,kete } \\
\text { rsediaan hara }\end{array}$ & L02d2 L02e2 L02i2 L02j2 L02k2 L0212 & & \\
\hline & & S3nr,n,eh & $\begin{array}{l}\text { Retensihara, } \\
\text { ketersediaan } \\
\text { hara, lereng }\end{array}$ & $\mathrm{L} 21 \mathrm{k} 3$ & 0.0834 & 1.46 \\
\hline \multirow[t]{2}{*}{2} & N1 & $\mathrm{N} 1 \mathrm{nr}, \mathrm{n}$ & $\begin{array}{l}\text { Retensi hara, } \\
\text { ketersediaan } \\
\text { hara }\end{array}$ & L11k1 L21k1 & 0.3225 & 5.64 \\
\hline & & N1 nr,n,eh & $\begin{array}{l}\text { Retensi hara, } \\
\text { ketersediaan } \\
\text { hara, lereng }\end{array}$ & L31f1 L31g1 L31h1 L31i1 L31k1 L3111 & 1.0221 & 17.88 \\
\hline \multirow[t]{2}{*}{3} & $\mathrm{~N} 2$ & $\mathrm{~N} 2 \mathrm{eh}$ & Lereng & L51f3 L51h3 L51k3 & 1.364 & 23.87 \\
\hline & & & & Total & 5.7176 & 100.00 \\
\hline
\end{tabular}

$\underline{\text { Kelas Kesesuaian Lahan N1 }}$

Kelas kesesuaian untuk lahan tidak sesuai (N1) terdapat pada area seluas 1.3446 ha atau $23.52 \%$ dari total luas lokasi penelitian. Kelas ini terbagi dalam dua sub kelas kesesuaian lahan, yaitu sub kelas (N1 n,nr), (N1 n,nr,eh).

a. Sub kelas kesesuaian lahan N1 n, nr memiliki luasan 0.3225 ha atau $5.64 \%$. Sub kelas ini memiliki faktor pembatas berupa ketersediaan hara dan retensi hara. Sub kelas kesesuaian lahan ini terdapat pada dua SPL, yaitu L11k1, L21k1.

b. Sub kelas kesesuaian lahan N1 n,nr,eh memiliki luasan 1.0221 ha atau $17.88 \%$. Sub kelas ini memiliki faktor pembatas berupa ketersediaan hara, retensi hara dan lereng. Sub kelas kesesuaian lahan ini tersebar dalam enam SPL, dengan SPL terbesar L31k1 (0.6534 ha atau $11.43 \%)$ dan lauasan terkecil adalah L3111 (0.0003 ha atau $0.01 \%)$.

\section{Kelas Kesesuian lahan N2}

Kelas kesesuaian untuk lahan tidak sesuai (N2) terdapat pada area seluas 1.3645 ha atau $23.87 \%$ dari total luas lokasi penelitian. Kelas ini terbagi dalam satu sub kelas kesesuaian lahan, yaitu sub kelas (N1 eh).

Sub kelas kesesuaian lahan N1 eh memiliki luasan 1.3645 ha atau $23.87 \%$. Sub kelas ini memiliki faktor pembatas berupa lereng. Sub kelas kesesuaian lahan ini tersebar dalam tiga SPL, dengan SPL terbesar L51k3 (1.2393 ha atau 21.68\%) dan luasan terkecil adalah L51h3 ( 0.0122 ha atau $0.21 \%$ ).

\section{Tindakan perbaikan untuk tiap faktor pembatas pada tanaman jagung}

Dalam menentukan jenis usaha perbaikan perlu diperhatikan karakteristik lahan yang menyusun masing-masing kualitas lahan. Karakteistik lahan dapat dibedakan menjadi karakteristik lahan yang dapat diperbaiki sesuai dengan tingkat pengelolaan yang akan diterapkan dan karakteristik lahan yang dapat diperbaiki. Tingkat pengelolaan menunjukan rendah, sedang atau tingginya biaya (modal) yang di perlukan sebagai implementasi usaha perbaiakan yang ditetapkan.

Dari hasil kesesuaian lahan aktual untuk beberapa satuan peta lahan di atas maka diperoleh sub kelas dimana yang merupakan faktor pembatas antara 
lain media perakaran (tekstur tanah) ketersediaan hara $\left(\mathrm{N}\right.$-total, $\left.\mathrm{P}_{2} \mathrm{O}_{5}\right)$ retensi hara $(\mathrm{KB})$ dan bahaya erosi (lereng).

$\underline{\text { Kesesuaian lahan potensial untuk tanaman }}$ jagung

Untuk sub kelas S3 rc,nr,n yang terdapat dalam satuan peta lahan L01a2 L01b2 L01d2 L01f2 L01g2 L01h2 L01i2 L01k2 L0112 L02a2 L02b2 L02c2 L02d2 L02e2 L02i2 L02j2 L02k2 L0212 L21k3, dimana faktor pembatasnya adalah tekstur tanah, KB, N_total, dan $\mathrm{P}_{2} \mathrm{O}_{5}$. Faktor pembatas tekstur tidak dapat dilakukan perbaikan, untuk faktor pembatas $\mathrm{KB}$ dapat dilakukan dengan cara pengapuran atau penambahan bahan organik dengan tingkat pengelolaan sedang sehingga kelas kesesuaian menjadi S2, sedangkan untuk faktor pembatas $\mathrm{N}$-total, dan $\mathrm{P}_{2} \mathrm{O}_{5}$ dapat dilakukan perbaikan dengan cara pemupukan dengan tingkat pengelolaan rendah sampai sedang, sehingga kelas kesesuian menjadi S2.

Untuk sub kelas N1 nr, n yang terdapat dalam satuan peta lahan L11k1 L21k1, dimana faktor pembatasnya adalah $\mathrm{KB}$, dan $\mathrm{P}_{2} \mathrm{O}_{5}$, untuk faktor pembatas $\mathrm{KB}$ dapat dilakukan dengan cara pengapuran atau penambahan bahan organik dengan tingkat pengelolaan sedang sehingga kelas kesesuaian menjadi S3, sedangkan untuk faktor pembatas $\mathrm{P}_{2} \mathrm{O}_{5}$ dapat dilakukan perbaikan dengan cara pemupukan dengan tingkat pengelolaan rendah sampai sedang sehingga kelas kesesuian menjadi S3.

Untuk sub kelas N1 nr,n,eh yang terdapat dalam satuan peta lahan L31f1 L31g1 L31h1 L31i1 L31k1 L3111, dimana faktor pembatasnya adalah $\mathrm{KB}, \mathrm{P}_{2} \mathrm{O}_{5}$ dan lereng. untuk faktor pembatas $\mathrm{KB}$ dapat dilakukan dengan cara pengapuran atau penambahan bahan organik dengan tingkat pengelolaan sedang sehingga kelas kesesuaian menjadi S3, untuk faktor pembatas $\mathrm{P}_{2} \mathrm{O}_{5}$ dapat dilakukan perbaikan dengan cara pemupukan dengan tingkat pengelolaan rendah sampai sedang sehingga kelas kesesuian menjadi S3, sedangkan untuk faktor pembatas lereng dapat dilakukan dengan cara pembuatan teras penanaman sejajar kontur atau penanaman tanaman penutup tanah sehingga kelas kesesuaian menjadi S3.

Untuk sub kelas N2 eh, yang terdapat dalam satuan petan lahan L51f3 L51h3 L51k3, dimana faktor pembatasnya adalah lereng untuk faktor pembatas ini tidak dapat dilakukan perbaiakan karena sulit diatasi dan memerlukan biaya yang sangat tinggi.

\section{Tindakan perbaikan untuk tiap faktor pembatas pada tanaman kelapa}

Dalam menentukan jenis usaha perbaikan perlu diperhatikan karakteristik lahan yang menyusun masing-masing kualitas lahan. Karakteistik lahan dapat dibedakan menjadi karakteristik lahan yang dapat diperbaiki sesuai dengan tingkat pengelolaan yang akan diterapkan dan karakteristik lahan yang dapat diperbaiki. Tingkat pengelolaan menunjukan rendah, sedang atau tingginya biaya (modal) yang di perlukan sebagai implementasi usaha perbaikan yang ditetapkan.

Dari hasil kesesuaian lahan aktual untuk beberapa satuan peta lahan diatas maka diperoleh sub kelas dimana merupakan faktor pembatas antara lain ketersediaan hara $\left(\mathrm{N}\right.$-total, $\left.\mathrm{P}_{2} \mathrm{O}_{5}\right)$ retensi hara $(\mathrm{KB})$ dan bahaya erosi (lereng) .

$\underline{\text { Kesesuaian lahan potensial untuk tanaman }}$ kelapa

Untuk sub kelas S3 nr,n yang terdapat dalam satuan peta lahan L01a2 L01b2 L01d2 L01f2 L01g2 L01h2 L01i2 L01k2 L0112 L02a2 L02b2 L02c2 L02d2 L02e2 L02i2 L02j2 L02k2 L0212 L21k3, dimana faktor pembatasnya adalah KB, KTK, N-total, dan $\mathrm{P}_{2} \mathrm{O}_{5}$. untuk faktor pembatas KB dan KTK dapat dilakukan dengan cara pengapuran atau penambahan bahan organik dengan tingkat pengelolaan sedang sehingga kelas kesesuaian menjadi S2, sedangkan untuk faktor pembatas $\mathrm{N}$-total, dan $\mathrm{P}_{2} \mathrm{O}_{5}$ dapat dilakukan perbaikan dengan cara pemupukan dengan tingkat pengelolaan rendah sampai sedang sehingga kelas kesesuian menjadi $\mathrm{S} 2$.

Untuk sub kelas S3 nr,n,eh yang terdapat dalam satuan peta lahan $\mathrm{L} 21 \mathrm{k} 3$, dimana faktor pembatasnya $\mathrm{KB}, \mathrm{N}$-total, $\mathrm{P}_{2} \mathrm{O}_{5}$ dan lereng. Untuk faktor pembatas KB dapat dilakukan dengan cara pengapuran atau penambahan bahan organik dengan tingkat pengelolaan sedang sehingga kelas kesesuaian menjadi S2, untuk faktor pembatas $\mathrm{N}$-total dan $\mathrm{P}_{2} \mathrm{O}_{5}$ dapat dilakukan perbaikan dengan cara pemupukan dengan tingkat pengelolaan rendah sampai sedang sehingga kelas kesesuian menjadi S2. Sedangkan untuk faktor pembatas lereng dapat dilakukan perbaikan dengan cara penanaman sejajar kontur atau penenaman tanaman penutup tanah dengan tingkat pengelolaan sedang sehingga kelas kesesuaian menjadi S2.

Untuk sub kelas N1 nr, n yang terdapat dalam satuan peta lahan L11k1 L21k1, dimana faktor pembatasnya adalah $\mathrm{KB}$, KTK, dan $\mathrm{P}_{2} \mathrm{O}_{5}$. untuk faktor pembatas KB dan KTK dapat dilakukan dengan cara pengapuran atau penambahan bahan organik dengan tingkat pengelolaan sedang sehingga kelas kesesuaian menjadi $\mathrm{S} 2$, sedangkan untuk faktor pembatas $\mathrm{P}_{2} \mathrm{O}_{5}$ dapat dilakukan perbaikan dengan cara pemupukan dengan tingkat pengelolaan rendah sampai sedang sehingga kelas kesesuian menjadi S3.

Untuk sub kelas N1 nr,n,eh yang terdapat dalam satuan peta lahan L31f1 L31g1 L31h1 L31i1 L31k1 L3111, dimana faktor pembatasnya $\mathrm{KB}, \mathrm{KTK}, \mathrm{P}_{2} \mathrm{O}_{5}$ dan lereng. untuk faktor pembatas, KB dan KTK dapat dilakukan dengan cara pengapuran atau penambahan bahan organik dengan tingkat pengelolaan sedang sehingga kelas kesesuaian menjadi S3, untuk faktor pembatas $\mathrm{P}_{2} \mathrm{O}_{5}$ dapat dilakukan perbaikan dengan cara pemupukan dengan tingkat pengelolaan rendah sampai sedang sehingga kelas kesesuian menjadi S3, sedangkan untuk faktor pembatas lereng dapat dilakukan dengan cara pembuatan teras penanaman sejajar kontur atau penanaman tanaman penutup tanah sehingga kelas kesesuaian menjadi S3. 
Untuk sub kelas N2 eh, yang terdapat dalam satuan peta lahan L51f3 L51h3 L51k3, dimana faktor pembatasnya adalah lereng untuk faktor pembatas ini tidak dapat dilakukan perbaikan karena sulit diatasi dan memerlukan biaya yang sangat tinggi.

\section{Faktor-faktor Pembatas}

Faktor pembatas merupakan seperangkat karakteristik lahan yang berpengaruh terhadap pertumbuhan serta produksi tanaman dan biasanya digunakan untuk penilaian kelas kesesuaian lahan. Dengan adanya faktor pembatas, kelas kesesuaian lahan sangat sesuai (S1) bisa menjadi cukup sesuai (S2), sesuai marginal (S3), tidak sesuai saat ini (N1), dan tidak sesuai selamanya (N2) berdasarkan faktor pembatas yang ditemukan.

Penilaian kelas kesesuaian lahan pada lokasi penelitian didasarkan pada faktor pembatas terberat. Berdasarkan hasil penelitian tersebut maka faktor pembatas yang ditemukan pada lokasi penelitian terdiri dari media perakaran, retensi unsur hara, ketersediaan hara, dan lereng.

\section{Perbaikan Faktor-faktor Pembatas}

Menurut Hardjowigeno dan Widiatmaka (2007), untuk menentukan usaha perbaikan yang dapat dilakukan maka harus diperhatikan karakteristik lahan yang tergabung dalam masing-masing kualitas lahan. Selanjumya dikemukakan bahwa Karakteristik lahan dapat dibedakan menjadi karakteristik lahan yang dapat diperbaiki dengan masukan sesuai dengan tingkat pengelolaan (teknologi) yang akan diterapkan dan karakteristik lahan yang tidak dapat diperbaiki.

\section{Faktor pembatas kejenuhan basa (KB) dan kapasitas tukar kation (KTK)}

Hasil penelitian menunjukkan bahwa faktor yang mempengaruhi retensi unsur hara di dalam tanah adalah KB dan KTK tanah. KB dan KTK tanah menggambarkan kemampuan koloid tanah dalam menyerap dan mempertukarkan kation atau dengan kata lain kemampuan tanah untuk mengikat basa-basa yang diperlukan oleh tanaman seperti $\mathrm{Ca}, \mathrm{Mg}, \mathrm{Na}$ dan $\mathrm{K}$ terhadap proses pencucian. Tanah dengan KTK tinggi mempunyai kemampuan menyerap dan menyediakan unsur hara lebih baik dari pada tanah dengan KTK rendah. Sedangkan nilai KB adalah persentase dari total kapasitas tukar kation (KTK) yang ditempati oleh kation-kation basa yang berhubungan dengan $\mathrm{pH}$ dan kesuburan tanah (Talakua dan Osok, 2019).

KTK tanah pada lokasi penelitian umumnya rendah berkisar dari 7,00 mg/100g-15,96 mg/100g. Agar mencapai tingkat KTK yang baik pertumbuhan dan produksi tanaman kelapa adalah tinggi (> 25 $\mathrm{mg} / 100 \mathrm{~g}$ ), tindakan perbaikan yang dapat dilakukan untuk mengatasi masalah ini adalah pemberian bahan organik. Sedangkan penilaian KB pada lokasi penelitian umumya rendah dari 7,00 mg/100 g-38 mg/100 g. nilai KB yang baik untuk pertumbuhan dan produksi tanaman kelapa adalah tinggi (>30 me/100 g). Dengan demikian tindakan perbaikan yang dapat dilakukan untuk mengatasi masalah ini adalah pemberian bahan organik dan pemgapuran. Menurut Hardjowigeno (2007) pada umumnya kation-kation basa mudah tercuci, sehingga tanah dengan kejenuhan basa tinggi menunjukkan bahwa belum banyak mengalami pencucian.

\section{Faktor pembatas $\mathrm{P}_{2} \mathrm{O}_{5}$}

Tanaman membutuhkan sejumlah unsur hara yang cukup dan tersedia untuk pertumbuhan dan produksinya. Unsur hara yang diperlukan oleh tanaman terbagi atas unsur hara makro dan unsur hara mikro.

Dalam penelitian ini, yang menjadi kriteria dalam penilaian kedalam kelas kesesuaian lahan (Haedjowigeno dan Widiatmaka, 2007) adalah $\mathrm{N}$ dalam bentuk Total-N, $\mathrm{P}$ dalam bentuk $\mathrm{P}_{2} \mathrm{O}_{5}$ tersedia dan $\mathrm{K}$ dalam bentuk $\mathrm{K}_{2} \mathrm{O}$ tersedia.

Hasil pengukuran kandungan fosfat $\left(\mathrm{P}_{2} \mathrm{O}_{5}\right.$ total $)$ di lokasi penelitian kandungan bervariasi dari rendah sampai sedang dengan nilai rata-rata sedang berkisar yaitu, $48 \mathrm{mg} / 100 \mathrm{~g}$ sampai yang yang terendah, yaitu $4,00 \mathrm{mg} / 100 \mathrm{~g}$. Jumlah fosfat phosfat di dalam tanah sangat bervariasi tergantung pada jenis tanahnya tetapi pada umumnya rendah (Handayanto dan Hairiyah, 2009). Kandungan fosfat yang rendah menyebabkan faktor pembatas atau kendala kesuburan tanah di lokasi penelitian, sehingga diperlukan penambahan cadangan fosfor ke dalam tanah. Unsur P di dalam tanah berasal dari bahan organik (pupuk kandang dan sisa-sisa tanaman), pupuk kimia (TSP) dan mineral-mineral di dalam tanah (apatit) (Hardjowigeno, 2003).

\section{Kesuburan Tanah}

\section{Komposisi kimia unsur dalam tanah}

Penilaian komposisi kimia unsur dalam tanah didasarkan pada hasil analisis contoh tanah minipit sebanyak 8 contoh disajikan pada Tabel 9.

Tabel 9 menunjukkan bahwa komposisi kapasitas tukar kation (KTK) semua sampel rendah. Nilai Kejenuhan basa (KB) berkisar dari sangat rendah sampai rendah; kandungan $\mathrm{C}$-Organik tanah berkisar dari sangat rendah sampai sedang; kandungan $\mathrm{P}_{2} \mathrm{O}_{5}$ berkisar dari sangat rendah sampai tinggi; $\mathrm{pH}$ tanah semua sampel bersifat masam; kandungan N-Total tanah semua sampel sangat rendah dan $\mathrm{K}_{2} \mathrm{O}$ berkisar dari sangat rendah sampai rendah.

\section{Ketersediaan unsur hara dalam tanah}

Berdasarkan komposisi kimia unsur hasil analisis laboratorium, dapat dihitung ketersediaan unsur dalam tanah. Hasil perhitungan kandungan unsur hara dalam tanah disajikan pada Tabel 9. 
Tabel 9. Rata-Rata komposisi kimia unsur setiap sampel tanah di lokasi penelitian

\begin{tabular}{|c|c|c|c|c|c|c|c|c|}
\hline \multirow{2}{*}{ UNSUR } & \multicolumn{8}{|c|}{ Nomor Sampel } \\
\hline & $\begin{array}{c}\text { RMP } \\
1.1 \\
\end{array}$ & $\begin{array}{c}\text { RMP } \\
1.2 \\
\end{array}$ & $\begin{array}{c}\text { RMP } \\
2.1 \\
\end{array}$ & $\begin{array}{c}\text { RMP } \\
2.2 \\
\end{array}$ & $\begin{array}{c}\text { RMP } \\
3.1 \\
\end{array}$ & $\begin{array}{c}\text { RMP } \\
3.2 \\
\end{array}$ & $\begin{array}{c}\text { RMP } \\
4.1 \\
\end{array}$ & $\begin{array}{c}\text { RMP } \\
4.2 \\
\end{array}$ \\
\hline KTK $(\mathrm{cmol} / \mathrm{kg})$ & 15,96 & 12,48 & 10,93 & 7,00 & 13,90 & 13,49 & 9,89 & 8,98 \\
\hline Kategori & $R$ & $R$ & $R$ & $R$ & $R$ & $R$ & $R$ & $R$ \\
\hline $\mathrm{KB}(\%)$ & 38 & 30 & 12 & 9 & 18 & 7 & 27 & 34 \\
\hline Kategori & $S$ & $R$ & $S R$ & $S R$ & $S R$ & $S R$ & $R$ & $R$ \\
\hline C-Organik (\%) & 2,98 & 0,82 & 2,87 & 1,72 & 3,00 & 0,87 & 1,87 & 1,00 \\
\hline Kategori & $R$ & $S R$ & $S$ & $R$ & $S$ & $S R$ & $R$ & $R$ \\
\hline $\mathrm{P}_{2} \mathrm{O}_{5}(\mathrm{ppm})$ & 17 & 6 & 17 & 8 & 10 & 4 & 48 & 31 \\
\hline Kategori & $S$ & $R$ & $S$ & $R$ & $R$ & $S R$ & $T$ & $T$ \\
\hline $\mathrm{pH}$ & 5,50 & 5,02 & 4,86 & 4,65 & 4,78 & 5,00 & 4,81 & 4,81 \\
\hline Kategori & $M$ & $M$ & $M$ & $M$ & $M$ & $M$ & $M$ & $M$ \\
\hline N-Total (\%) & 0,08 & 0,08 & 0,08 & 0,08 & 0,08 & 0,08 & 0,07 & 0,08 \\
\hline Kategori & $S R$ & $S R$ & $S R$ & $S R$ & $S R$ & $S R$ & $S R$ & $S R$ \\
\hline $\mathrm{K}_{2} \mathrm{O}(\mathrm{ppm})$ & 198 & 107 & 82 & 6 & 91 & 30 & 51 & 48 \\
\hline Kategori & $R$ & $R$ & $S R$ & $S R$ & $S R$ & $S R$ & $S R$ & $S R$ \\
\hline
\end{tabular}

Sumber : Hasil olah data penelitian; Keterangan : $S R=$ sangat rendah; $R=$ rendah; $S=$ sedang; $T=$ Tinggi; $S T=$ sangat tinggi $; M$ = masam $; A M=$ agak masam $; S M=$ sangat masam

Tabel 10. Kandungan unsur hara dalam tanah

\begin{tabular}{lcccccccc}
\hline \multirow{2}{*}{ UNSUR } & \multicolumn{10}{c}{ Nomor Sampel } \\
\cline { 2 - 9 } & RMP 1.1 & RMP 1.2 & RMP 2.1 & RMP 2.2 & RMP 3.1 & RMP 3.2 & RMP 4.1 & RMP 4.2 \\
\hline N-Total (Kg/ha) & 16 & 16 & 16 & 16 & 16 & 16 & 14 & 16 \\
$\mathrm{P}_{2} \mathrm{O}_{5}$ (Kg/ha) & 7,8 & 2,7 & 7,8 & 3,7 & 4,6 & 1,8 & 22,0 & 14,2 \\
$\mathrm{~K}_{2} \mathrm{O}$ (Kg/ha) & 47,7 & 25,8 & 19,8 & 1,4 & 21,9 & 7,2 & 12,3 & 11,6 \\
\hline
\end{tabular}

Sumber : Hasil olah data penelitian

Tabel 11. Status kesuburan tanah lokasi penelitian

\begin{tabular}{lcccccccc}
\hline \multirow{2}{*}{ Unsur Kimia } & \multicolumn{1}{c}{ Nomor Sampel } & \multicolumn{1}{c}{} \\
\cline { 2 - 8 } & RMP & RMP & RMP & RMP & RMP & RMP & RMP & RMP \\
& 1.1 & 1.2 & 2.1 & 2.2 & 3.1 & 3.2 & 4.1 & 4.2 \\
\hline KTK (cmol/kg) & 11,96 & 12,48 & 10,93 & 7,00 & 13,90 & 13,49 & 9,89 & 8,98 \\
Kategori & $R$ & $R$ & $R$ & $R$ & $R$ & $R$ & $R$ & $R$ \\
KB (\%) & 38 & 30 & 12 & 9 & 18 & 7 & 27 & 34 \\
Kategori & $R$ & $R$ & $S R$ & $S R$ & $S R$ & $S R$ & $R$ & $R$ \\
BO (\%) & 2,98 & 0,82 & 2,87 & 1,72 & 3,00 & 0,87 & 1,87 & 1,00 \\
Kategori & $R$ & $S R$ & $S$ & $R$ & $S$ & $S R$ & $R$ & $R$ \\
P-Tersedia (ppm) & 17 & 6 & 17 & 8 & 10 & 4 & 48 & 31 \\
Kategori & $S$ & $R$ & $S$ & $R$ & $R$ & $S R$ & $T$ & $T$ \\
Status Kesuburan & $R$ & $R$ & $S R$ & $S R$ & $R$ & $S R$ & $R$ & $R$ \\
Tanah & & & & & & &
\end{tabular}

Sumber: Hasil olah data penelitian

\section{Status kesuburan tanah}

Penilaian status kesuburan tanah pada lokasi penelitian dilakukan dengan membandingkan kandungan unsur di dalam tanah hasil analisis laboratorium dengan kriteria status kesuburan tanah. Hasil penilaian tersebut tertera pada Tabel 11.

\section{KESIMPULAN}

Berdasarkan hasil dan pembahasan dapat disimpulkan dan disarankan sebagai berikut:

1. Kelas kesesuaian untuk tanaman jagung adalah S3 sub kelas S3rc,nr,n (faktor pembatas media perakaran, retensi hara ketersediaan hara), N1 sub kelas N1nr,n,eh (faktor pembatas retensi hara, 
ketersediaan hara dan lereng), N2 sub kelas N2eh (faktor lereng).

2. Kelas kesesuaian untuk tanaman kelapa adalah S3 sub kelas S3rc,nr,n (faktor pembatas media perakaran, retensi hara ketersediaan hara), N1 sub kelas N1nr,n,eh (faktor pembatas retensi hara ketersediaan hara dan lereng), N2 sub kelas N2eh (faktor lereng).

3. Rekomendasi pemanfaatan lahan sebagai berikut :

a. Untuk tanaman jagung: Untuk mengatasi faktor pembatas $\mathrm{KB}$ dapat dilakukan dengan cara pengapuran atau penambahan bahan organik dengan tingkat pengelolaan sedang sehingga kelas kesesuaian menjadi S3, untuk faktor pembatas $\mathrm{P}_{2} \mathrm{O}_{5}$ dapat dilakukan perbaikan dengan cara pemupukan dengan tingkat pengelolaan rendah sampai sedang sehingga kelas kesesuian menjadi S3. Sedangkan untuk mengatasi faktor pembatas lereng dapat dilakukan dengan cara pembuatan teras penanaman sejajar kontur atau penanaman tanaman penutup tanah sehingga kelas kesesuaian menjadi S3.

b. Untuk tanaman kelapa: Untuk mengatasi faktor pembatas $\mathrm{KB}$ dapat dilakukan dengan cara pengapuran atau penambahan bahan organik dengan tingkat pengelolaan sedang sehingga kelas kesesuaian menjadi S2, untuk faktor pembatas $\mathrm{N}$-total dan $\mathrm{P}_{2} \mathrm{O}_{5}$ dapat dilakukan perbaikan dengan cara pemupukan dengan tingkat pengelolaan rendah sampai sedang sehingga kelas kesesuian menjadi S2. Sedangkan untuk mengatasi faktor pembatas lereng dapat dilakukan perbaikan dengan cara penanaman sejajar kontur atau penenaman tanaman penutup tanah dengan tingkat pengelolaan sedang sehingga kelas kesesuaian menjadi S2.

\section{DAFTAR PUSTAKA}

Djaenudin, D., H. Marwan, H. Subagyo, A. Mulyani, dan N. Suharta. 2000. Kriteria Kesesuaian Lahan untuk Komoditas Pertanian. Versi 3.0. Puslittanak, Badan Litbang Pertanian, Jakarta.

Hafif, B., J. Barus, and Misganti. 2013. Zoning rural area for the development of annual plants.
International Journal on Advanced Science Engineering Informat Ion Technology 3(1): 3337. DOI: $10.18517 /$ ijaseit.3.1.272

Hanafiah, K.A. 2008. Dasar-dasar Ilmu Tanah. Jakarta : PT. Raja Grafindo Persada. Jakarta.

Handayanto, E. dan K. Hairiah. 2009. Biologi Tanah Landasan Pengelolaan Tanah Sehat, Cetakan Kedua. Pustaka Adipura, Yogyakarta.

Hardjowigeno, S. 2007. Ilmu Tanah, Cetakan ke 6. Akademika Pressindo. Jakarta.

Hardjowigeno, S. dan Widiatmaka, 2007. Evaluasi Kesesuaian Lahan dan Perencanaan Tataguna Lahan. Gadjah Mada University Press, Yogyakarta.

Lehmann, A. and K. Stahr. 2010. The potential of soil functions and planner-oriented soil evaluationto achieve sustainable land use. Journal of Soils Sediments $\quad 10$ : 1092-1102. DOI: 10.1007/s11368-010-0207-5

Louhenapessy, J.E. 2004. Refleksi Evaluasi Lahan Dalam Konteks Pembangunan Pertanian Berkelanjutan. Sintesis Pemikiran Ilmiah Untuk Pembangunan Wilayah Kepulauan Di Indonesia. Kumpulan Pidato Guru Besar Universitas Pattimura, Edisi I. Ambon

Oldeman, L.R. 1975. Contribution: An Agroclimatic map of Java and Madura. Central Research Institute for Agriculture. Bogor.

Schmidt, F.H. and J.H.A. Ferguson. 1951. Rainfall type based on wet and dry period ratio for Indonesia with Western New Gurinea. Kementerian Perhubungan. Jakarta.

Soil Survey Staff. 2014. Keys To Soil Taxonomy, Twelfth Edition. United States Department of Agriculture Natural Resources Conservation Service. Washington.

Talakua, S.M. 2016. Degradasi Lahan Metode Analisis dan Aplikasinya dalam Penggunaan Lahan. Penerbit Plantaxia. Yogyakarta.

Talakua, S.M. dan R.M. Osok. 2019. Development of a land degradation assessment model based on field indicators assessment and prediction methods in Wai Sari, Sub-Watershed Kairatu District, Western Seram Regency, Maluku Province, Indonesia. Science Nature 2(1): 66-70. 